\title{
DAMPAK EKONOMI AKIBAT IUU FISHING PERIKANAN TANGKAP PELAGIS BESAR DI WPPNRI 715
}

\section{Economic Impact of IUU Fishing on Big Pelagic Fish in WPPNRI 715}

\author{
*Annis Susanti, Achmad Fahrudin, dan Tridoyo Kusumastanto
}

Institut Pertanian Bogor

\author{
Kampus IPB Darmaga, Jalan Agatis, Babakan, Dramaga, Kota Bogor, Jawa Barat, Indonesia \\ Diterima tanggal: 29 September 2019 Diterima setelah perbaikan: 2 Oktober 2020 \\ Disetujui terbit: 23 Desember 2020
}

\begin{abstract}
ABSTRAK
Penelitian ini bertujuan untuk mengetahui dampak ekonomi akibat IUU fishing pada perikanan tangkap pelagis besar di WPPNRI 715. Metode penelitian yang digunakan adalah metode penelitian studi kasus dengan teknik pengambilan sampel menggunakan multistage random sampling, metode analisis data yang digunakan adalah bioekonomi model. Penelitian dilakukan pada bulan Desember 2018 sampai dengan Agustus 2019 dan sampling pengambilan data di provinsi Sulawesi Utara dan DKI Jakarta. Hasil analisis menunjukkan bahwa produksi legal ikan pelagis besar pada maximum economic yield (MEY) adalah sebesar 368.522,25 ton per tahun dengan effort sebanyak 554902 trip per tahun dan perolehan rente sebesar Rp3,06 trilyun/tahun sedangkan produksi total (legal dan IUU fishing) adalah sebesar 530.451,63 ton per tahun dengan effort sebanyak 929414 trip per tahun dan rente sebesar Rp6,73 trilyun/tahun. IUU fishing menimbulkan dampak hilangnya potensi perolehan rente ekonomi pada pemanfaatan sumber daya ikan pelagis besar di WPPNRI 715 yaitu sebesar Rp3,66 trilyun/tahun. Hasil penelitian menyimpulkan bahwa IUU fishing merugikan perikanan tangkap pelagis besar di WPPNRI 715 sehingga diperlukan rumusan kebijakan dalam pengawasan sumberdaya kelautan dan perikanan berupa peningkatan kualitas sumberdaya manusia dalam bidang perikanan, penggunaan satelit pemantauan dan kebijakan peningkatan kesadaran dan penegakkan hukum di laut.
\end{abstract}

Kata Kunci: IUU Fishing; WPPNRI 715; perikanan pelagis; ikan pelagis besar; bioekonomi; rente ekonomi

\begin{abstract}
This research aims to determine the economic impact of IUU fishing large pelagic fish in WPPNRI 715. The research is a case study with multistage random sampling. Data were analysed with bioeconomics model for fisheries. The research was conducted from December 2018 to August 2019, and the sampling areas of data collection was in the provinces of North Sulawesi and DKI Jakarta. The results of the analysis showed that the legal production of large pelagic fish at maximum economic yield (MEY) is 368,522.25 tons per year with an effort of 554902 trips per year, and economic rent at IDR3.06 trillions/year. The total production (legal and IUU fishing) is 530,451.63 tons per year with an effort of 929.414 trips per year and economic rent of IDR 6.73 trillions/year. IUU fishing has an impact on the loss of potential economic rent on the large pelagic fish resources in the WPPNRI 715 amounting to IDR 3.66 trillion/year. The results showed that IUU fishing has a detrimental economic impact on the large pelagic fish in WPPNRI 715. Therefore, a policy is necessary to increase supervision of marine and fishery resources by improving the quality of fishery human resources, the use of monitoring satellites and policies to increase awareness and law enforcement at sea.
\end{abstract}

Keywords: IUU Fishing; WPPNRI 715; pelagic fishery; large pelagic fish; bioeconomic; economic rent 


\section{PENDAHULUAN}

IUU fishing merupakan permasalahan yang rawan terjadi di berbagai negara termasuk di Indonesia, kejahatan yang terorganisasi akibat keserakahan, kesalahan kontrol pemerintah dan penegakan hukum yang lemah. IUU fishing menurut FAO (2019) merupakan kegiatan penangkapan ikan secara ilegal dalam area laut lepas dan dalam wilayah yuridiksi nasional seperti aspek penangkapan dan pemanfaatan ikan. IUU fishing dikategorikan dalam tiga kelompok dalam Dahuri (2017): (1) Illegal fishing yaitu kegiatan penangkapan ikan dilakukan oleh kapal-kapal nasional asing di perairan yang berada di bawah yurisdiksi suatu negara tanpa seizin dari negara itu, bertentangan dengan hukum dan peraturannya, atau dilakukan oleh kapal-kapal yang beroperasi tanpa melakukan langkah-langkah konservasi dan pengelolaan yang bertentangan, dan dilakukan oleh kapal-kapal yang melanggar hukum nasional maupun internasional dalam FAO (2019), (2) Unregulated fishing yaitu kegiatan penangkapan di perairan wilayah atau ZEE suatu negara yang tidak mematuhi atauran yang berlaku di negara tersebut, (3) Unreported fishing yaitu kegiatan penangkapan ikan diperairan wilayah atau ZEE suatu negara yang tidak dilaporkan baik operasionalnya, data kapal dan hasil tangkapannya.

IUU fishing sangat terorganisasi dan merupakan kejahatan transnasional karena keterkaitan satu dengan yang lain Bondarof, Teale, Reitano, Tuesday \& Wietsey (2015). Pada The Contemporary English Indonesian Dictionary, Illegal artinya tidak sah, dilarang atau bertentangan dengan hukum (Salim, 2003) dan fishing artinya penangkapan ikan, sehingga illegal fishing berarti penangkapan ikan secara tidak sah dan bertentangan dengan hukum. Kerugian akibat illegal fishing diperkirakan sebesar Rp 27 trilyun sampai Rp 54 trilyun setiap tahunnya (Nikijuluw, 2008), sedangkan menurut Widodo bahwa illegal fishing telah mengakibatkan kerugian ekonomi sebesar 20 milyar dolar AS per tahun dalam Aini (2016). Kegiatan illegal fishing di perairan Indonesia sangat merugikan Negara Indonesia setiap tahunnya, menurut Menteri Kelautan dan Perikanan Negara Republik Indonesia Susi Pudjiastuti dalam Daniel (2014) kerugian mencapai Rp 240 trilyun dan merupakan faktor penghambat pemanfaatan potensial maksimal perikanan Indonesia dalam IUU Control in The Exclusive Economic Zone dijelaskan bahwa penanganan IUU fishing di ZEE kurang memadai dan menimbulkan efek merugikan nelayan dan negara (Rosello, 2016). Upaya untuk melawan illegal fishing diperairan Indonesia yaitu: pengembangan sistem pengawasan, pengembangan industri perikanan terpadu, regionalisasi pengelolaan sumber daya, perbaikan sistem perizinan, sistem pengawasan dan pengembangan sistem peradilan perikanan dalam Neka (2010) .

Eksploitasi sumber daya ikan seharusnya dilakukan secara hati-hati, bertanggung jawab, sesuai dengan peraturan yang berlaku (legal) sehingga keberlanjutan dan kesejahteraan dapat terwujud. WPPNRI 715 merupakan salah satu dari sebelas (11) Wilayah Pengelolaan Perikanan Negara Republik Indonesia (WPPNRI) sesuai dengan Peraturan Menteri Kelautan dan Perikanan Republik Indonesia Nomor 18/PERMEN-KP/2014 tentang Wilayah Pengelolaan Perikanan Negara Republik Indonesia. Potensi sumber daya ikan pada WPPNRI 715 diestimasi cukup melimpah yaitu sebanyak631.703 ton/tahun (Kementerian Kelautan dan Perikanan Nomor Nomor 50/KEPMEN-KP/2017 tentang Estimasi Potensi, Jumlah Tangkapan Yang Diperbolehkan, dan Tingkat Pemanfaatan Sumber daya Ikan di Wilayah Pengelolaan Perikanan Negara Republik Indonesia. WPPNRI 715 termasuk salah satu wilayah pengelolaan perikanan Negara Republik Indonesia yang rawan tindak kejahatan IUU fishing, selain berbatasan dengan perairan teritorial negara tetangga Filipina potensi sumber daya ikan pelagis besar yang melimpah menjadi daya tarik luar biasa karena memiliki nilai ekonomi yang tinggi. Praktik IUU fishing yang terjadi di WPPNRI 715 tidak hanya dilakukan oleh pihak asing, tetapi juga oleh para nelayan/pengusaha lokal (Dahuri, 2017) yang dikenal dengan kapal ikan Indonesia (KII) dan kapal ikan asing (KIA). Illegal, unreported, and unregulated (IUU) fishing melemahkan pengelolaan sumber daya perikanan, karena hasil tangkapan ikan tidak terpantau dan mengakibatkan kerugian baik secara ekonomi maupun biologi bagi Negara Republik Indonesia. Penyumbang terbesar tindak IUU fishing di WPPNRI 715 yaitu sebanyak $89 \%$ adalah KII dengan pelanggaran berupa tidak adanya dokumen perizinan penangkapan ikan, pemalsuan dokumen perizinan, daerah penangkapan ikan (fishing ground) tidak sesuai dengan SIPI, penggunaan anak buah kapal (ABK) asing, tidak dilengkapi transmitter, tidak memiliki surat laik operasi (SLO), tidak memiliki surat perintah berlayar (SPB) dan pelabuhan singgah tidak sesuai SIKPI (surat ijin kapal pengangkut ikan). 
Sumber daya ikan merupakan sumber makanan, mata pencarian dan sumber pendapatan bagi pertumbuhan ekonomi negara (Adrianto, 2005). Kehancuran sumber daya ikan akan memiskinkan nelayan dan negara, pemanfaatan sumber daya ikan yang tidak bertanggung jawab mengancam pemanfaatan sumber daya perikanan yang berkelanjutan. Menurut Frust, Helming, Loiz, Muller \& Verbug. (2013) menyatakan bahwa pentingnya penilaian ekonomi perikanan tangkap dengan berbagai pendekatan dalam pengelolaan ekonomi perikanan tangkap disuatu wilayah mengingat perbedaaan sumber daya dan karakteristik wilayah. Oleh karena itu penelitian ini dilakukan untuk mengetahui optimal berapa besar dampak ekonomi akibat IUU Fishing pada perikanan tangkap pelagis besar di WPPNRI 715.

\section{METODOLOGI}

\section{Metode Penelitian}

Metode penelitian adalah cara-cara dalam melakukan penelitian sehingga dihasilkan temuan yang dapat diyakini kebenarannya (kesahihannya) secara ilmiah sehingga dapat digunakan sebagai dasar dalam mengambil keputusan atau kebijakan (Kusumastanto, 2014). Metode penelitian yang digunakan adalah studi kasus (case study). Menurut Macfield dalam Nazir (2013) studi kasus merupakan penelitian tentang status subyek penelitian yang berkenaan dengan suatu fase spesifik atau khas dari keseluruhan personalitas dan merupakan penelitian yang mengeksplorasi suatu sistem yang terikat, sebuah kasus atau beberapa kasus yang terjadi selama kurun waktu tertentu melalui pengumpulan data yang mendalam dan terperinci dari berbagai sumber informasi yang dapat dipercaya kebenaran persaksiannya (Creswell, 1988). Studi kasus dipilih peneliti karena mendukung studi yang besar dikemudian hari, memberikan hipotesa-hipotesa lanjutan dan menghasilkan ilustrasi yang baik bagi perumusan masalah untuk membuat rumusan kesimpulan.

\section{Lokasi dan Waktu Penelitian}

Penelitian dilakukan di WPPNRI 715 dengan pengambilan data dilakukan sampling di dua provinsi yaitu Provinsi Sulawesi Utara dan Provinsi DKI Jakarta (Kementerian Kelautan dan Perikanan, 2016). Penelitian berlangsung selama sembilan bulan mulai bulan Desember 2018 sampai dengan bulan Agustus 2019 dimulai tahap persiapan penelitian berupa penyusunan proposal penelitian, pembuatan kuesioner, observasi lapangan, pengumpulan data primer dan data sekunder sampai pada tahap pengolahan data, penyusunan model dan verifikasi model.

\section{Jenis dan Sumber Data}

Jenis dan sumber data yang digunakan dalam peneltian ini adalah data primer dan data sekunder. Data primer diperoleh langsung dari sampel lokasi penelitian dengan cara pemberian kuesioner, wawancara, fokus grup Diskusi (FGD) dan pengamatan penelitian secara langsung terhadap kondisi, fenomena-fenomena dalam pengelolaan perikanan pelagis besar pada WPPNRI 715 dan tindak IUU fishing. Untuk data sekunder pengumpulan data dilakukan dari berbagai lembaga perikanan yaitu Kementerian Kelautan dan Perikanan, Badan Pusat Statistik, Dinas Kelautan dan Perikanan dan instansi terkait lainnya.

\section{Metode Pengambilan Contoh}

Teknik pengambilan contoh dari penelitian ini dilakukan dengan metode multi stage sampling. Pada kasus khusus dari cluster sampling, dimana pada tahap kedua kita tidak memilih semua elemen dari cluster, tetapi beberapa elemen yang dipilih dengan cara acak dalam Barreiro \& Justo (2001). Multistage sampling digunakan untuk memperoleh data primer meliputi data harga ikan (hasil produksi), struktur biaya usaha penangkapan ikan, pola usaha perikanan, wilayah tangkapan ikan, kelembagaan masyarakat nelayan, kebijakan pemerintah dan manfaatnya bagi nelayan, biaya dan hasil tangkapan sebelum dan sesudah kebijakan. Metode pengambilan contoh menggunakan berbagai metode random sampling secara bersama-sama se-efisien dan se-efektif mungkin. Penentuan sampel responden pada setiap titik dibedakan atas alat tangkap yang digunakan dan ukuran kapal penangkap ikan pelagis besar di WPPNRI 715 dengan masing-masing kelompok responden tersebut minimal 30 responden yang ditentukan sesuai tujuan penelitian.

\section{Metode Analisis Data}

Model bioekonomi dijadikan dasar oleh peneliti untuk menganalisis data dengan mengestimasi besaran sumber daya perikanan tangkap yang dapat dimanfaatkan (Zulbainarni, 2012). Estimasi parameter biologi sumber daya perikanan tangkap pelagis besar pada WPPNRI 715 dilakukan dengan menggunakan model 
produksi surplus yang merupakan pengembangan model biologi yang dikembangkan Schaefer (1954) menunjukan bahwa setiap spesies ikan memiliki kemampuan untuk berproduksi melebihi kapasitas produksi sehingga apabila ikan ditangkap tidak melebihi dan tidak kurang maka stok ikan akan tetap bertahan dan berkesinambungan (Fauzi, 2010). Berikut model pertumbuhan logistik Clark (1985):

$$
F(x)=r x\left(1-\frac{x}{K}\right)
$$

Keterangan/Remarks:

$$
\begin{aligned}
& F(x) \quad=\text { Perubahan stokikan (fungsi pertumbuhan } \\
& x=\text { Stok ikan/Biomass } \\
& r \quad=\text { Laju pertumbuhan intrinsik ikan/Intrinsic } \\
& \text { Growth Rate } \\
& K=\text { Kapasitas daya dukung lingkungan } \\
& \text { Carrying Capacity }
\end{aligned}
$$

Dalam pemanfaatan sumber daya ikan ada faktor input berupa upaya penangkapan ikan (effort) maka produksi perikanan dinyatakan dalam fungsi Clark (1985):

$$
h=q x E
$$

$$
\text { Keterangan/Remarks: }
$$

$$
\begin{aligned}
h & =\text { Produksi/Harvest } \\
q & =\text { Koefesien daya tangkap/Catchability } \\
& \text { coefficient } \\
x & =\text { Stok ikan/Biomass } \\
E & =\text { Upaya penangkapan/Fishing effort }
\end{aligned}
$$

Untuk menentukan jumlah upaya penangkapan (effort) dilakukan perhitungan standarisai alat tangkap. Standarisasi dilakukan untuk mengetahui alat tangkap yang dijadikan standar bagi perhitungan upaya penangkapan standar (effort standard), rumus standarisasi upaya penangkapan dalam Sobari \& Diniah (2009):

$$
F P I=\frac{\text { CPUE } i}{\text { CPUES }}
$$

Maka : $f_{s}=F P I x f_{i}$

Keterangan/Remarks:

$$
\text { FPI = } \begin{aligned}
\text { Indeks daya tangkap/Fishing power } \\
\text { index }
\end{aligned}
$$

CPUEi $=$ CPUE alat tangkap yang distandarisasi Catch per unit effort will be standardized CPUEs = CPUE alat tangkap standar/Catch per
unit effort standard
$f_{s} \quad=$ Upaya penangkapan hasil standarisasi
$f_{i} \quad=$ Upaya penangkapan yang distandarisasi Fishing effort will be standardized

Sehingga upaya penangkapan optimal untuk menghasilkan Maximum Economic Yield (MEY) dapat diperkirakan dengan menggunakan persamaan berikut dalam Budi, Fauzi, Fahrudin \& Purnomo (2015):

$M E Y=r \frac{K}{4}\left(\frac{c}{2 p}\right)^{2}\left(\frac{r}{q^{2}} K\right)$

Rente ekonomi dari pemanfaatan sumber daya ikan pelagis besar pada WPPNRI 715 dituliskan dalam persamaan berikut (Purwanto, 1988):

$$
\begin{aligned}
\pi & =T R-T C \\
& =p\left(a E-b E^{2}\right)-c E
\end{aligned}
$$

Dampak ekonomi akibat IUU fishing (Hermanto, 2018) pada perikanan tangkap pelagis besar di WPPNRI 715 dirumuskan menjadi:

$$
\begin{aligned}
& T R^{*}=p \cdot Q=p\left(a E-b E^{2}\right)+\text { Illegal fishing } \\
& T C=c . E \\
& \text { Maka: } \\
& \pi^{*}=T R^{*}-T C \\
& \quad=\left(p\left(a E-b E^{2}\right)+\text { Illegal fishing }\right)-c E
\end{aligned}
$$

Keterangan/Remarks:

$$
\begin{array}{ll}
c & =\text { Biaya persatuan upaya/Cost per unit effort } \\
E & =\text { Tingkat upaya penangkapan/Fishing effort } \\
T C= & \text { Total biaya (biaya tetap }+ \text { biaya variabel) } \\
& \text { Total cost (Fixed cost + Variable cost) } \\
T R= & \text { Total penerimaan/Total revenue }
\end{array}
$$

\section{HASIL DAN PEMBAHASAN}

\section{Pendugaan Parameter}

Kelompok jenis ikan pelagis besar merupakan potensi terbesar yaitu sebanyak 31659 ton yang ada pada WPPNRI 715 (PERMEN KP Nomor 50/KEPMEN-KP/2017) diluar ikan tuna dan cakalang, dibandingkan kelompok ikan lainnya. Dalam pendugaan parameter bioteknik sumber daya perikanan tangkap pelagis besar pada WPPNRI 715 dilakukan perhitungan untuk menentukan catch per unit effort (CPUE) yaitu produksi hasil tangkapan ikan pelagis besar per alat tangkap dibagi dengan upaya penangkapan (effort) 
per alat tangkap berdasarkan data statistik perikanan tangkap tahun 2016 dan data pelabuhan perikanan tahun 2017 dan tahun 2018. Catch per unit effort (CPUE) adalah suatu metode yang digunakan untuk menentukan hasil jumlah produksi perikanan laut yang dirata-ratakan dalam tahunan sehingga akan diketahui produksi perikanan di suatu wilayah penangkapan apakah megalami kenaikan atau penurunan produksi dalam Fauzi (2010). Alat tangkap yang digunakan lebih dari satu alat tangkap (multi gear) dengan hasil tangkapan ikan pelagis besar lebih dari satu jenis ikan (multi species) yaitu pukat cincin (purse seine), huhate (pole and line), pancing ulur (handline), rawai tuna (longline tuna) dan jaring insang oceanic (oceanic gill net). Berikut nilai catch per unit effort (CPUE) pada setiap alat tangkap dapat dilihat pada Tabel 1.

CPUE per alat tangkap pada perikanan tangkap pelagis besar legal pada WPPNRI 715 menunjukan nilai produktivitas alat tangkap pukat cincin (purse seine) memiliki rata-rata tertinggi dibandingkan alat tangkap lainnya, sehingga alat tangkap pukat cincin (purse seine) menjadi alat tangkap standar yang mempunyai nilai FPI sama dengan satu (=1), sedangkan nilai $\mathrm{FPI}$ alat tangkap lain diperoleh dari nilai CPUE alat tangkap lain dibagi dengan nilai CPUE alat tangkap yang dijadikan standar.

Untuk mengetahui dampak IUU fishing terhadap perikanan tangkap pelagis besar di WPPNRI 715 perlu dihitung terlebih dahulu berapa banyak data kapal IUU fishing yang ditangkap dengan spesifikasi masing-masing ukuran GT kapal, alat tangkap yang digunakan, jumlah trip kapal dan produksi perikanan yang diperoleh. Kemudian dihitung CPUE total yaitu CPUE legal dan CPUE IUU fishing. Data IUU fishing diperoleh dari data hasil tangkapan operasi kapal pengawas Direktorat Jenderal PSDKP Kementerian Kelautan dan Perikanan Republik Indonesia di WPPNRI 715 pada Tahun 2011 sampai dengan Tahun 2018. Hasil CPUE total dapat dilihat pada Tabel 2.

Tabel 1. CPUE Legal Perikanan Pelagis Besar di WPPNRI 715, Tahun 2011-2018. Table 1. CPUE Legal of Large Pelagic Fish in WPPNRI 715, Period of 2011-2018.

\begin{tabular}{|c|c|c|c|c|c|}
\hline \multirow{2}{*}{$\begin{array}{l}\text { Tahun/ } \\
\text { Year }\end{array}$} & \multicolumn{5}{|c|}{ Upaya Penangkapan per Unit Alat Tangkap/ Catch Per Unit Effort (CPUE)Ton/trip/Ton/trip } \\
\hline & $\begin{array}{l}\text { Pukat Cincin/ } \\
\text { Purse Seine }\end{array}$ & $\begin{array}{l}\text { Huhate/Pole } \\
\text { and Line }\end{array}$ & $\begin{array}{l}\text { Pancing Ulur/ } \\
\text { Handline }\end{array}$ & $\begin{array}{l}\text { Rawai Tunal } \\
\text { Longline Tuna }\end{array}$ & $\begin{array}{c}\text { Jaring Insang Oceanic/ } \\
\text { Oceanic Gillnet }\end{array}$ \\
\hline 2011 & 0.8031 & 1.0060 & 0.0104 & 0.4421 & 0.0780 \\
\hline 2012 & 0.7167 & 0.2263 & 0.0442 & 0.1026 & 0.0684 \\
\hline 2013 & 1.0129 & 0.3695 & 0.0169 & 0.3691 & 0.0631 \\
\hline 2014 & 0.6815 & 0.7845 & 0.0298 & 0.4015 & 0.1206 \\
\hline 2015 & 0.5810 & 1.0664 & 0.0263 & 0.0498 & 0.0786 \\
\hline 2016 & 0.6179 & 0.2160 & 0.0200 & 0.2728 & 0.0995 \\
\hline 2017 & 0.6466 & 0.2311 & 0.0204 & 0.3144 & 0.0001 \\
\hline 2018 & 0.6368 & 0.2258 & 0.0205 & 0.2729 & 0.0995 \\
\hline Jumlah/Total & 5.6966 & 4.1254 & 0.1886 & 2.2252 & 0.6076 \\
\hline Rata-rata/ & 0.7121 & 0.5157 & 0.0236 & 0.2782 & 0.0759 \\
\hline
\end{tabular}

Sumber: Hasil Analisis Data, 2019/Source: Data Analysis, 2019

Tabel 2. Total CPUE (legal + illegal) Perikanan Pelagis Besar di WPPNRI 715, Tahun 2011-2018. Table 2. Total CPUE of Large Pelagic Fish in WPPNRI 715, Period of 2011-2018.

\begin{tabular}{|c|c|c|c|c|c|}
\hline \multirow{2}{*}{$\begin{array}{l}\text { Tahun/ } \\
\text { Year }\end{array}$} & \multicolumn{5}{|c|}{ Upaya Penangkapan per Unit Alat Tangkap/ Catch Per Unit Effort (CPUE) Ton/trip/Ton/trip } \\
\hline & $\begin{array}{l}\text { Pukat Cincin/ } \\
\text { Purse Seine }\end{array}$ & $\begin{array}{c}\text { Huhate/Pole } \\
\text { and Line }\end{array}$ & $\begin{array}{l}\text { Pancing Ulur/ } \\
\text { Handline }\end{array}$ & $\begin{array}{l}\text { Rawai Tuna/ } \\
\text { Longline Tuna }\end{array}$ & $\begin{array}{c}\text { Jaring Insang Oceanic/ } \\
\text { Oceanic Gillnet }\end{array}$ \\
\hline 2011 & 0.8256 & 1.0060 & 0.0106 & 0.4502 & 0.0780 \\
\hline 2012 & 0.7228 & 0.2263 & 0.0444 & 0.1028 & 0.0684 \\
\hline 2013 & 1.0133 & 0.3695 & 0.0169 & 0.3691 & 0.0631 \\
\hline 2014 & 0.7197 & 0.7845 & 0.0298 & 0.4015 & 0.1206 \\
\hline 2015 & 0.5869 & 1.0664 & 0.0264 & 0.0498 & 0.0786 \\
\hline 2016 & 0.6179 & 0.2160 & 0.0200 & 0.2728 & 0.0995 \\
\hline 2017 & 0.6504 & 0.2311 & 0.0205 & 0.3144 & 0.0001 \\
\hline 2018 & 0.6368 & 0.2258 & 0.0205 & 0.2729 & 0.09995 \\
\hline Jumlah/Total & 5.7735 & 4.1254 & 0.1891 & 2.2252 & 0.6076 \\
\hline Rata-rata/Average & 0.7217 & 0.5157 & 0.0236 & 0.2782 & 0.0759 \\
\hline
\end{tabular}

Sumber: Hasil Analisis Data, 2019/Source: Data Analysis, 2019 
Berdasarkan data penangkapan ikan pelagis besar pada WPPNRI 715 diperoleh nilai produktivitas alat tangkap purse seine memiliki rata-rata tertinggi dibandingkan alat tangkap lainnya, sehingga alat tangkap purse seine menjadi alat tangkap standar yang mempunyai nilai FPI sama dengan satu (Octoriani, 2016), sedangkan nilai FPI alat tangkap lain diperoleh dari nilai CPUE alat tangkap lain dibagi dengan nilai CPUE alat tangkap yang dijadikan standar. Masingmasing alat tangkap ikan pelagis besar pada WPPNRI 715 baik pukat cincin (purse seine), huhate (pole in line), pancing ulur (handline), rawai tuna (longline tuna) dan jaring insang oceanic memiliki kemampuan yang berbedabeda dalam menangkap ikan pelagis besar di WPPNRI 715, untuk itu diperlukan standarisasi alat tangkap dengan menghitung fishing power index (FPI) dalam menstandarisasi alat tangkap ikan pelagis besar di WPPNRI 715. Standarisasi alat tangkap dilakukan dengan menghitung Fishing Power Index (FPl) adalah tingkat kemampuan alat tangkap dalam menangkap ikan dalam upaya menyeragamkan besarnya nilai upaya penangkapan ikan (effort standard) dari lima jenis alat tangkap ikan pelagis besar di WPPNRI 715. Hasil perhitungan nilai standar alat tangkap per upaya penangkapan legal (legal effort standard) dapat dilihat pada Tabel 3.

Data produksi perikanan legal dan IUU fishing di WPPNRI 715 tahun 2011 - 2018, dapat dilihat pada Gambar 1.

Maka total nilai standar alat tangkap (effort standard) per alat tangkap ikan pelagis besar di WPPNRI 715 legal dan IUU fishing dapat dilihat pada Tabel 4.

Tabel 3. Nilai Standar Alat Tangkap pada Perikanan Tangkap Pelagis Besar Legal di WPPNRI 715 Tahun 2011-2018.

Table 3. Legal Value of Effort Standard Large Pelagic Fish in WPPNRI 715, Period of 2011-2018.

\begin{tabular}{cccccc}
\hline \multirow{2}{*}{$\begin{array}{c}\text { Tahun/ } \\
\text { Year }\end{array}$} & \multicolumn{5}{c}{$\begin{array}{c}\text { Upaya Penangkapan per Unit Alat Tangkap/ } \\
\text { Catch Per Unit Effort (CPUE)Ton/trip/Ton/trip }\end{array}$} \\
\cline { 2 - 6 } & $\begin{array}{c}\text { Pukat Cincin/ } \\
\text { Purse Seine }\end{array}$ & $\begin{array}{c}\text { Huhatel } \\
\text { Pole In line }\end{array}$ & $\begin{array}{c}\text { Pancing Ulurl } \\
\text { Handline }\end{array}$ & $\begin{array}{c}\text { Rawai Tuna/ } \\
\text { Longline Tuna }\end{array}$ & $\begin{array}{c}\text { Jaring Insang } \\
\text { Oceanic/ Gillnet }\end{array}$ \\
\hline 2011 & 39,052 & 69,697 & 105,681 & 17,983 & 39,035 \\
2012 & 55,085 & 71,838 & 181,107 & 20,644 & 57,606 \\
2013 & 43,553 & 45,311 & 156,671 & 11,289 & 31,911 \\
2014 & 82,775 & 52,286 & 136,805 & 19,807 & 45,557 \\
2015 & 147,551 & 70,663 & 206,829 & 16,742 & 60,700 \\
2016 & 192,603 & 92,643 & 236,007 & 27,719 & 93,365 \\
2017 & 229,567 & 115,773 & 290,899 & 32,428 & 64 \\
2018 & 199,293 & 97,867 & 248,231 & 27,996 & 94,239 \\
\hline
\end{tabular}

Sumber: Hasil Analisis Data, 2019/Source: Data Analysis, 2019

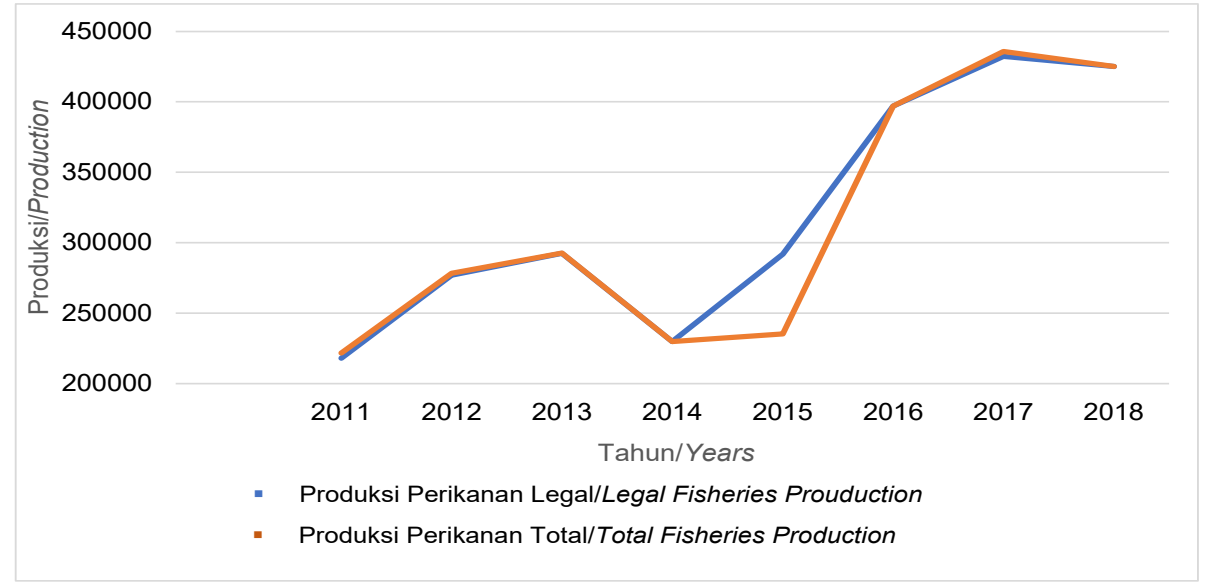

Gambar 1. Produksi Perikanan Tangkap Pelagis Besar di WPPNRI 715.

Figure 1. Production of Large Pelagic Fish in WPPNRI 715.

Sumber: Hasil Analisis Data, 2019/Source: Data Analysis, 2019 
Tabel 4. Total Nilai Standar Alat Tangkap (Effort Standard) pada Perikanan Tangkap Pelagis Besar di WPPNRI 715, Tahun 2011-2018.

Table 4. Total Value of Effort Standard for Large Pelagic Fish in WPPNRI 715, Period of 2011-2018.

\begin{tabular}{cccccc}
\hline \multirow{2}{*}{$\begin{array}{c}\text { Tahun/ } \\
\text { Year }\end{array}$} & \multicolumn{3}{c}{ Upaya Penangkapan per Unit Alat Tangkap/Catch Per Unit Effort (CPUE)Ton/trip/Ton/trip } \\
\cline { 2 - 5 } & $\begin{array}{c}\text { Pukat Cincin/ } \\
\text { Purse seine }\end{array}$ & $\begin{array}{c}\text { Huhate/ } \\
\text { Pole in Line }\end{array}$ & $\begin{array}{c}\text { Pancing Ulurl } \\
\text { Handline }\end{array}$ & $\begin{array}{c}\text { Rawai tuna/ } \\
\text { Longline tuna }\end{array}$ & $\begin{array}{c}\text { Jaring Insang } \\
\text { Oceanic/ Gillnet }\end{array}$ \\
\hline 2011 & 31,854 & 55,641 & 86,937 & 14,836 & 31,163 \\
2012 & 175,133 & 227,565 & 578,900 & 65,502 & 182,480 \\
2013 & 119,500 & 124,228 & 429,891 & 30,952 & 87,490 \\
2014 & 71,918 & 45,424 & 125,804 & 17,207 & 39,578 \\
2015 & 80,801 & 38,499 & 113,894 & 9,121 & 33,071 \\
2016 & 551,059 & 265,061 & 675,242 & 79,308 & 267,127 \\
2017 & 643,663 & 323,915 & 827,634 & 90,729 & 178 \\
2018 & 562,174 & 276,067 & 700,222 & 78,973 & 265,832 \\
\hline
\end{tabular}

Sumber: Hasil Analisis Data, 2019/Source: Data Analysis, 2019

Jumlah produksi perikanan tangkap pelagis besar pada WPPNRI 715 akibat IUU fishing berdampak pada hilangnya potensi rente ekonomi para pelaku usaha penangkapan ikan legal dapat dilihat pada Tabel 5 .

\section{Pendugaan Kerugian Aktual IUU Fishing}

Dampak IUU Fishing pada perikanan tangkap di WPPNRI 715 menyebabkan daya dukung perairan $(K)$ menurun sebagai akibat dari meningkatnya koefesien daya tangkap perikanan (q) dan laju pertumbuhan intrinsik (r). IUU fishing melemahkan pengelolaan sumber daya perikanan, karena hasil tangkapan ikan illegal fishing tidak terpantau dan mengakibatkan potensi hilangnya rente ekonomi bagi negara Indonesia. Berikut hasil perhitungan kerugian aktual kehilangan rente ekonomi akibat IUU Fishing pada perikanan tangkap pelagis besardiWPPNRI715, sebagaimana dapat dilihat pada Tabel 6 .

Rente ekonomi (economic rent) yang hilang akibat IUU fishing pada pemanfaatan sumber daya ikan pelagis besar di WPPNRI 715 yaitu sebesar Rp3,6 trilyun/tahun dapat dilihat pada Gambar 2.

Kegiatan illegal fishing tersebut adalah fakta kerugian negara, dan implikasi kebijakannya adalah menutup pengeluaran izin penangkapan untuk kapal ikan asing dan meningkatkan pengamanan operasi penangkapan berdasarkan izin yang sudah dikeluarkan (Rahardjo, 2013) dan optimalisasi sumber daya perikanan mempertimbangkan kesesuaian aspek ekologi, ekonomi dan sosial secara berkelanjutan (Naufal, 2016). Kurva dampak IUU fishing pada rente ekonomi di WPPNRI 715 dapat dilihat pada Gambar 3.

Tabel 5. Parameter Biologi Perikanan Pelagis Besar di WPPNRI 715, Tahun 2011-2018.

Table 5. Biological Parameters for Large Pelagic Fish in WPPNRI 715, Period of 2011-2018.

\begin{tabular}{clcc} 
Koefesien/ & Keterangan/ Definition & \multicolumn{2}{c}{ Nilai/Value } \\
\cline { 3 - 4 } Coefficient & Sesuai Aturan/Legal & Melanggar/IUU Fishing \\
\hline $\mathrm{r}$ & Laju Pertumbuhan Intrinsik/ Intrinsic Growth Rate & 1.4673520650 & 2.8994491247 \\
$q$ & Koefesien Daya Tangkap/ Catchability coefficient & 0.0000008520 & 0.0000013113 \\
$\mathrm{k}$ & Daya Dukung Perairan/ Carrying Capacity & $1,150,022.89$ & $750,863 / 85$ \\
\hline
\end{tabular}

Sumber: Hasil Analisis Data, 2019 /Source: Data Analysis, 2019

Tabel 6. Nilai Kehilangan Rente Ekonomi Akibat IUU Fishing Perikanan Tangkap Pelagis Besar di WPPNRI 715, Tahun 2011-2018.

Table 6. Economic Rent Losses of IUU Fishing on Large Pelagic Fish in WPPNRI 715, Period of 2011-2018.

\begin{tabular}{lcrr}
\hline & \multicolumn{2}{c}{$\begin{array}{c}\text { Hasil Ekonomi Maksimum/ } \\
\text { Maximum Economic Yield (MEY) }\end{array}$} & $\begin{array}{c}\text { Rente Ekonomi yang Hilang/ } \\
\text { Ecomonic Rent Lost }\end{array}$ \\
\cline { 2 - 4 } & $\begin{array}{c}\text { Sesuai Aturan/ } \\
\text { Legal }\end{array}$ & $\begin{array}{c}\text { Total/Total } \\
\text { (Legal+/UU Fishing) }\end{array}$ & \\
\hline Produksi/Harvest (ton) & $368,522.25$ & $530,451.63$ & \\
Upaya penangkapan/Effort (trip) & 554.902 & 929,414 & \\
Rente/Rent (Juta Rp./Million IDR.) & $3,065,588.97$ & $6,731,009.05$ & $(3,665,420.08)$ \\
\hline
\end{tabular}




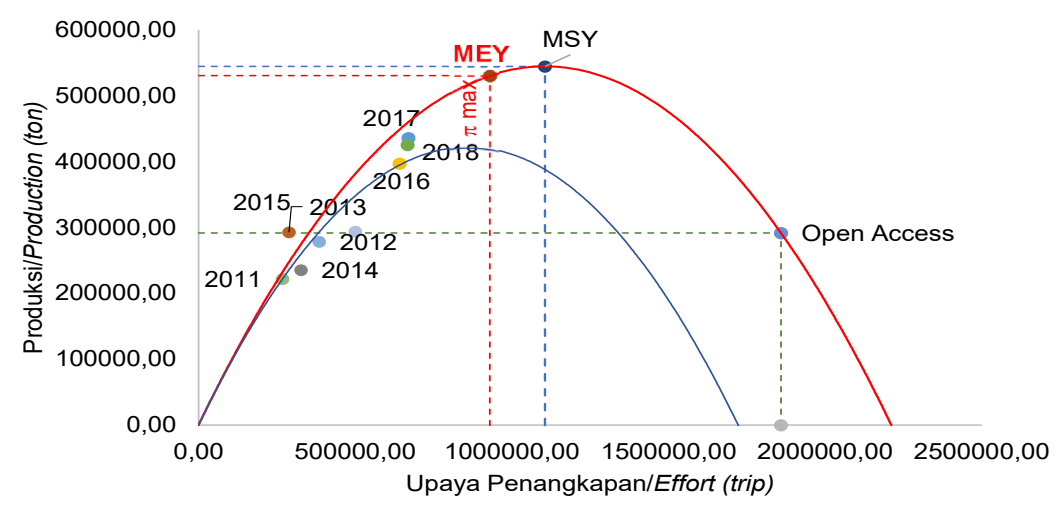

Gambar 2. Kurva Dampak IUU Fishing Pelagis Besar di WPPNRI 715, Figure 2. Impact Curve IUU Fishing of Large Pelagic Fish in WPPNRI 715.

Sumber: Hasil Analisis Data, 2019 /Source: Data Analysis, 2019

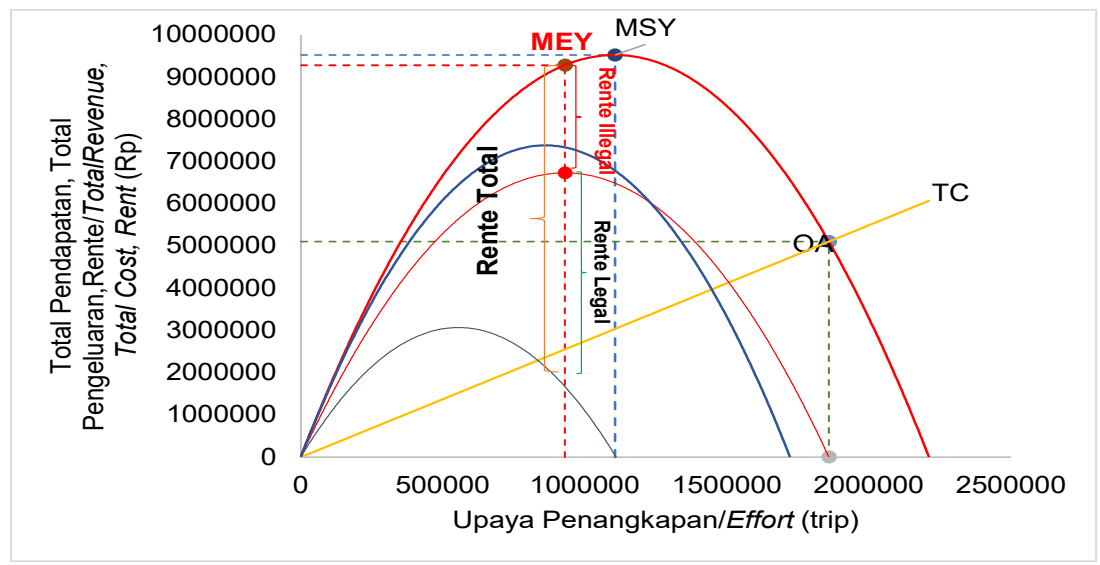

Gambar 3. Kurva Dampak IUU Fishing terhadap Hilangnya Rente Ekonomi Perikanan Pelagis Besar di WPPNRI 715.

Figure 3. Impact Curve on IUU Fishing of The Economic Rent Loss of Large Pelagic Fish in WPPNRI 715.

Sumber: Hasil Analisis Data, 2019 /Source: Data Analysis, 2019

\section{KESIMPULAN DAN REKOMENDASI KEBIJAKAN}

\section{Kesimpulan}

Tindak kejahatan IUU fishing di WPPNRI 715 berdasarkan hasil analisis menunjukkan bahwa produksi legal ikan pelagis besar pada maximum economic yield (MEY) adalah sebesar 368 522,25 ton per tahun dengan effort sebanyak 554902 trip per tahun dan perolehan rente sebesar Rp3,06 trilyun/tahun sedangkan produksi total (legal dan IUU fishing) adalah sebesar 530451,63 ton per tahun dengan effort sebanyak 929414 trip per tahun dan rente sebesar Rp6,73 trilyun/tahun. Hasil penelitian menyimpulkan bahwa IUU fishing merugikan perikanan tangkap pelagis besar di WPPNRI 715 yaitu hilangnya rente ekonomi atas pemanfaatan sumber daya perikanan tangkap pelagis besar di WPPNRI 715 yaitu sebesar Rp 3,6 trilyun/tahun, sehingga diperlukan kebijakan penegakan hukum terhadap kegiatan IUU fishing dengan peningkatan pengawasan sumber daya kelautan dan perikanan.

\section{Rekomendasi Kebijakan}

Wilayah Pengelolaan Perikanan Negara Republik Indonesia (WPPNRI) 715 dengan potensi sumber daya perikanan tangkap pelagis besar yang cukup tinggi membutuhkan kebijakan peningkatan pengawasan sumber daya kelautan dan perikanan dalam memberantas tidak kejahatan IUU fishing dengan rekomendasi kebijakan perbaikan regulasi terkait pengawasan (compliance) dan law enforcement yaitu kebijakan terkait pemberian ijin bidang perikanan sejalan dengan kapasitas 
kemampuan yang akan melakukan pengawasan. Hal ini akan berdampak pada pelaku IUU fishing untuk tidak mengulangi perbuatannya. Mengingat kasus IUU fishing yang banyak terjadi di WPPNRI 715 adalah berupa transshipment, destructive fishing, penggunaan alat tangkap yang dilarang dan pelanggaran perijinan.

Pembentukan Pokmaswas yang dibentuk oleh masyarakat setempat yaitu untuk memperkuat kelembagaan pengawasan di masyarakat, karena pengawasan secara individu kurang efektif dibandingkan dengan pengawasan yang dilakukan oleh banyak orang (kelompok masyarakat). Kearifan lokal akan lebih efektif memberikan efek jera dibandingkan dengan hukum positif yang membutuhkan banyak waktu dan biaya.

Penguatan kelembagaan pada Unit Pelaksana Teknis (UPT) PSDKP yang mencakup area di WPPNRI 715 serta konsistensi pemerintah dalam kebijakan terkait IUU Fishing, karena saat ini kebijakan sering tidak konsisten, kebijakan dan regulasi sering berubah-ubah serta kajian terkait IUU Fishing seharusnya berkelanjutan, dapat digunakan oleh siapapun dan tidak memulai dari awal lagi.

Peningkatan Sumber daya Manusia dalam pengawasan yaitu jumlah dan kualitas Pengawas Perikanan dan PPNS Perikanan masih belum memadai. Peningkatan teknis kemampuan pengawasan dan penyidikan harus menjadi prioritas. Aspek pemberdayaan masyarakat juga merupakan rekomendasi yaitu berupa pemberdayaan ekonomi masyarakat karena kawasan konservasi di WPPNRI 715 dapat menjadi kekuatan ekonomi masyarakat setempat melalui penangkapan ikan yang ramah lingkungan, budidaya perikanan dan wisata bahari. Untuk itu diperlukan kampanye penyadaran kepada masyarakat yang diharapkan dapat mengurangi tindak kejahatan IUU Fishing. Masyarakat akan memiliki kesadaran bahwa hidup mereka sangat tergantung dengan keberlanjutan sumber daya perikanan.

Peningkatan sarana dan prasarana pengawasan yaitu dengan penggunaan radar satelit yang real time, mengingat bahwa WPPNRI 715 memiliki banyak kawasan konservasi perairan dan potensi tuna cukup besar, sehingga jika menggunakan radar satelit akan lebih bisa melingkupi pengawasan dibandingkan mengunakan kapal pengawas dan penguatan armada tangkap masyarakat nelayan berupa bantuan kapal, alat tangkap dan cold storage yang tepat sasaran kepada masyarakat nelayan.

\section{UCAPAN TERIMA KASIH}

Terima kasih disampaikan kepada Prof. Sonny Koeshendrajana, Bapak Waluyo Sejati Abutohir, S.H., M.M, Bapak Ir. Purwanto, M.S., Ph. D, Dr. Agus Suherman, S.Pi., M.Si., Andan Hamdani, rekan-rekan Direktorat Jederal Perikanan Tangkap Kementerian Kelautan dan Perikanan, rekan-rekan Direktorat Jenderal Pengawasan Sumber daya Kelautan dan Perikanan Kementerian Kelautan dan Perikanan, rekan-rekan Balai Besar Sosial Ekonomi Kelautan dan Perikanan, rekan-rekan Dinas Kelautan dan Perikanan Provinsi Sulawesi Utara dan kota Bitung, rekan-rekan Badan Pusat Statistik Provinsi Sulawesi Utara, rekan-rekan BAPPEDA Provinsi Sulawesi Utara dan Kota Bitung serta semua rekan pada program studi Ekonomi Sumber daya Kelautan Tropika Institut Pertanian Bogor atas semua bantuan dan dukungan baik berupa data, metode, materi, kesempatan serta dukungan lainnya, sehingga artikel jurnal ini dapat diterbitkan.

\section{PERNYATAAN KONTRIBUSI PENULIS}

Dengan ini kami menyatakan bahwa kontribusi masing-masing penulis terhadap pembuatan karya tulis adalah: Annis Susanti sebagai kontributor utama, Achmad Fahrudin dan Tridoyo Kusumastanto sebagai kontributor anggota. Penulis menyatakan bahwa telah melampirkan surat pernyataan kontribusi penulis.

\section{DAFTAR PUSTAKA}

Adrianto, L. (2005). Implementasi Code of Conduct for Responsible Fisheries dalam Perspektif Negara Berkembang. Indonesian J International Law, 2(3), 463-482.

Aini, N. (2016). Dampak Illegal Fishing Luar Biasa. Yogyakarta (ID), Republika.co.id.

Barreiro, P. L. \& Justo, P.A. (2001). Population and Sample: Sampling Techniques. Management Mathematics for European Schools. Retrieved from http://www. mathematik.unikl.de/ rmamaeusch.

Bondaroff, P., Teale, N., Reitano, Tuesday \& Wietsey, W. (2015). The Illegal Fishing and Organizied Crime Nexus: Illegal Fishing as Transnational Organized Crime. Geneva $(\mathrm{CH})$ : The Global Initiative Against Transnational Organized Crime and The Black Fish. 
Budi, W., Fauzi, A., Fahrudin, A., \& Purnomo, A. H. (2015). Total Faktor Produktivitas dan Instabilitas Perikanan Tangkap. Jurnal Sosial Ekonomi Kelautan dan Perikanan, 10(1).

Clark, C. (1985). Bioeconomic Modelling and Fisheries Management. John Wiley and Sons. New York.

Creswell. (1988). Qualitative Inquiry And Research Design: Choosing Among Five Traditions. London: SAGE Publications.

Daniel, W. (2014). Menteri Susi, Kerugian Akibat Illegal Fishing Rp 240 Trilyun. Diakses dari : http:// finance.detik.com/read/2014/12/01/152125/276 4211/4/menteri-susi-kerugian-akibat-illegal-fishing-rp-240-trilyun tanggal: 16 Desember 2017.

Dahuri, R. (2017). Menuju Indonesia Sebagai Poros Maritim Dunia. Bogor, ID: Roda Bahari.

Direktorat Jenderal PSDKP. (2011). Nusantara Lestari Jaya. Buku Organisasi Direktorat Jenderal PSDKP. Jakarta.

Direktorat Jenderal Perikanan Tangkap. (2016). Statistik Perikanan Menurut Wilayah Pengelolaan Perikanan Negara Republik Indonesia. Jakarta.

Fauzi, A. (2010). Ekonomi Perikanan. Teori, Kebijakan dan Pengelolaan (edisi: Teori dan Aplikasi. Jakarta, ID: PT. Gramedia Pustaka Utama.

Frust, C., Helming, K., Loiz, C., Muller, F.,\& Verbug , P. H. (2013). Integrated Land Use and Regional Resources Management-A Cross Dissciplinary Dialogue Perspective For a Sustainable Development of Regional Resources. J Environmental Management. 127: S1-S5.

FAO. (2019). "What is IUU Fishing?" Food and Agriculture Organization of the United Nations. Retrieved from https://www.fao.org/iuu-fishing/background/ what-is-iuu-fishing/en/

Hermanto, D. (2018). Model Pengawasan Kelautan Dalam Pengelolaan Ekonomi Perikanan Tangkap Pelagis Kecil Pada WPP 711. Diakses dari: https://repository.ipb.ac.id/jspui/bitstream/123456 789/92653/1/2018dhe.pdf.

Kementerian Kelautan dan Perikanan. (2009). Peraturan Menteri Nomor 1 Tahun 2009 dan Peraturan Menteri Nomor 18 Tahun 2014 tentang Wilayah Pengelolaan Perikanan Negara Republik Indonesia.

Kementerian Kelautan dan Perikanan. (2016). Peraturan Menteri Nomor 47/KEPMEN-KP/2016 tentang Estimasi Potensi, Jumlah Tangkapan Yang Diperbolehkan, dan Tingkat Pemanfaatan Sumber daya Ikan di WPPNRI.

Kusumastanto, T. (2014). Metodologi Penelitian Ekonomi Sumber daya Kelautan Tropika. Bogor, ID: PKSPL-IPB.
Naufal, A., Kusumastanto, T., \& Fahrudin, A. (2016). Kajian Ekonomi Model Pengelolaan Sumber daya Perikanan Cakalang di Pantai Utara Aceh. Jurnal Aplikasi Manajemen-Journal of Applied Management, 14(2).

Nazir, M. (2013). Metode Penelitian. Bogor, ID: Penerbit Ghalia Indonesia.

Nikijuluw, V. P. H. (2008). Blue Water Crime: Dimensi Sosial Ekonomi Perikanan Illegal. Jakarta, ID: PT. Pustaka Cidesindo.

Neka, A. (2010). Analisis Penanggulangan Illegal Fishingdi Kabupaten Halmahera Utara. Diakses dari: https://repository.ipb.ac.id. Bogor.

Octoriani, W., Fahrudin, A., Boer, \& Menofatria. (2016). Laju Eksploitasi Sumber Daya Ikan yang Tertangkap Pukat Cincin di Selat Sunda (Exploitation Rate of Fisheries Resources which Caught by Purse seine in Sunda Strait). Journal of Marine Fisheries Technology and Management, $6(1)$.

Purwanto. (1988). Bio-Ekonomi Penangkapan Ikan : Model Statik. Jurnal Oseana, Volume XIV. Nomor 2 : 63-72,1988 100 ISSN 02161877.

Rahadjo, M. (2013). Analisis Nilai Kerugian Akibat Illegal Fishing di Laut Arafura Tahun 2001-2013. J Oktopus, Vol 1-8p.

Rosello, M. (2016). Illegal, Unreported and Unregulated Fishing Control in The Exclusive Economic Zone: A Brief Appraisal of Regulatory Deficits and Accountability Strategies. J CIRR, 12(75): 39-68.

Sobari, M.P., \& Diniah, I. (2009). Kajian Bio-Ekonomi dan Investasi Optimal Pemanfaatan Sumber daya Ikan Ekor Kuning di Perairan Kepulauan Seribu. Jurnal Mangrove dan Pesisir, 9(2): 56-66.

Salim, P. (2003). The Contemporary English Indonesian Dictionary. Jakarta, ID: Modern English Press.

Schaefer, M. B. (1954). Some Aspects of The Dynamics of Populations Importance to The Management of Commercial Marine Fisheries. Bull. Intern-Am. Trop. Tuma Com. 1: 27-56.

Undang-Undang Nomor 45 Tahun 2009. (2009). Tentang Perubahan Atas Perundang-undangan Indonesia Nomor 31 Tahun 2004 Tentang Perikanan. Tanggal 29 Oktober 2009.

Zulbainarni, N. (2012). Teori dan Praktek Permodelan Bioekonomi dalam Pengelolaan Perikanan Tangkap. Bogor, ID: IPB Press, edisi revisi. 